\title{
CARBON SEQUESTRATION POTENTIAL OF PLANTS USED IN THE BEAUTIFICATION AND GREENING OF IKEJA METROPOLIS, LAGOS,
} NIGERIA

\author{
Osinaike, Titilola Savier \\ Department of Botany \\ Lagos State University, Ojo, Lagos, Nigeria
}

\section{Adejobi, M. J}

Centre for Environment and Science Education

Lagos State University, Ojo, Lagos, Nigeria

Ojekale, Anthony B.

Department of Biochemistry

Lagos State University, Ojo, Lagos, Nigeria

Abstract - This study evaluated the efficiency and effectiveness of carbon sequestration of plants used in the beautification and greening of Ikeja metropolis, Lagos State (South West, Nigeria). The efficiency of carbon sequestration of plants was extrapolated from foliar chlorophyll content of each plant. The results showed that in areas with ornamental plants, the level of carbon dioxide is relatively low compared to areas without plants. Along the Lagos State University Teaching Hospital (LASUTH)/Bank Anthony location, the mean carbon dioxide concentration in areas without plants was $17.10 \pm 0.06 \mathrm{mg} / \mathrm{ml}$ while areas within the same location but with plants have a carbon dioxide concentration of $6.91 \pm 1.73 \mathrm{mg} / \mathrm{ml}$. It was observed that, Terminalia catappa (Almond) has the greatest sequestration efficiency; with mean total chlorophyll content of $1.00 \pm 0.02 \mathrm{mg} / \mathrm{l}$ while Murraya paniculata (Murraya exotic) has a mean total chlorophyll content of $0.41 \pm 0.03 \mathrm{mg} / \mathrm{l}$. The results of the research showed that plants found in the area sequester carbon efficiently with Terminalia catappa (Almond) and Polyalthia longifolia (Masquerade) having highest carbon sequestration potentials when compared to the shrubs. basis for a formal and on-going carbon management programme, with the potential to do more. This research provides a useful foundation for future action on carbon sequestration in the state and country at large. It could form the basis to inform the on-going management of carbon sequestration, including the planning of new planting and decisions regarding the management of

\author{
Onyemeka, Regland Michael \\ Department of Botany \\ Lagos State University, Ojo, Lagos, Nigeria
}

\author{
Meduoye, Omoyeni Andrew \\ Department of Botany \\ Lagos State University, Ojo, Lagos, Nigeria \\ Ogun, Mautin Lawrence \\ Department of Botany \\ Lagos State University, Ojo, Lagos, Nigeria
}

mature trees to improve the state's and country's environmental reputation.

Keywords - Carbon sequestration; climate change; Carbon dioxide: chlorophyll; Photosynthesis

\section{INTRODUCTION}

Since the dawn of the industrial revolution, the burning of fossil fuel and land use changes have released a lot of greenhouse gas-((carbondioxide $\left.\left(\mathrm{CO}_{2}\right)\right)$, resulting in global warming and a series of environmental problems (Solomon et al., 2007; IPCC, 2013). Chlorophyll is an extremely important, critical in photosynthesis; its content in plant leaves indicates their photosynthetic capacity. Photosynthesis is the major direct way by which $\mathrm{CO}_{2}$ in the atmosphere is fixed back to the earth (Speer, 1997). Increase in chlorophyll content increases photosynthesis activities of the plant thus increase in $\mathrm{CO}_{2}$ fixed from the atmosphere. As the re-growth of forest can absorb $\mathrm{CO}_{2}$ effectively; much attention has been paid to forest fixed Carbon (Fang et al., 2007). It is an effective measure for alleviating globa1 warming ((Andrasko, 1990 and Brown et al., 1993). With the signing of the Kyoto Protocol in 1997 coupled with the implementation of policies to reduce global warming, research and application of forest Carbon sink has been given a lot of attention (Cannel et al., 1999 and Dai et al., 2004). The Importance of forested areas in carbon sequestration is already accepted, and well documented (Tiwari and Singh, 1987) and as such there have been lots of research works on the carbon sequestration 


\section{International Journal of Engineering Applied Sciences and Technology, 2019 \\ Vol. 4, Issue 7, ISSN No. 2455-2143, Pages 217-221 \\ Published Online November 2019 in IJEAST (http://www.ijeast.com)}

potentials of closed forests, open forests, woodlands, woody savannahs and woodlots at different levels (Brown, 1997). Lagos and Nigeria at large could benefit from the targeted interventions that would reduce the local air pollution and help the country to tackle greenhouse gas emissions (Oyedepo, 2012). Carbon sequestration potentials of trees is one of such intervention, however continued existence of trees species in Lagos is already in jeopardy; because deforestation, logging and other various forms of unsustainable activities have drastically increased in recent times, thereby posing appreciable risk of local extinction to some tree species (Nodza et al., 2014). Therefore this study focuses on the carbon sequestration efficiency of trees and shrubs used in the beautification and greening of Ikeja metropolis of Lagos State, South West Nigeria to mitigate the $\mathrm{CO} 2$ emissions caused by various human operations.

\section{MATERIALS AND METHODS}

\section{A. Site Description}

The study area was Ikeja metropolis, an outer-ring suburb of the city of Lagos and the capital of Lagos State. Ikeja is one of the constitutionally recognized 774 Local Government Areas (LGAs) in Nigeria. It lies between latitudes $6.35^{\circ} \mathrm{N}$ and $6.583^{\circ} \mathrm{N}$, longitude $3.45^{\circ} \mathrm{E}$ and $3.75^{\circ} \mathrm{F}$. The area has a humid tropical climate characterized by distinct dry and wet seasons with moderate mean annual rainfall which varies between $1381.7 \mathrm{~mm}$ and $2733.4 \mathrm{~mm}$. The area has two discernible seasons viz: rainy season (from March to early July and from September to early November with break in late July and August) and dry seasons (between August and September and between December and March). It has a temperature ranging between $29^{\circ} \mathrm{C}-34^{\circ} \mathrm{C}$, the lowest being in the month of July and the highest in March. The relative humidity is generally high and rarely below $70 \%$ throughout the year (Akanni, 1992). The study was carried out in three different locations in Ikeja metropolis where trees and shrubs are used in abundance for beautification purpose. Table 1 indicates the location and plants found in the location.

\section{B. Sample Analysis}

\section{Height of trees}

The mature plant species were sampled in the three locations. The height of the plant species were measured using the trigonometry method of Kerson et al. (1993) and Zobeing (2004).

\section{Air Sample Analysis}

A Land duo multi flue gas analyzer (Testo 350XL) was used to determine the carbon dioxide concentration around the trees. Air sample was taken at point 10 metres and 15 metres away from the trees, and the sample collections were replicated three times. Air was also sampled similarly in areas with and without trees, but within the same environment.

\section{Leaf Sample Analysis}

Extraction and estimation of chlorophyll content was estimated using the method described by Arnon, (1949). Total chlorophyll content was calculated by summing results of chlorophyll a and that of chlorophyll b for each sample taken. A total of 12 samples for each plant were taken at the different locations. $3 \mathrm{~g}$ of fresh leaves were blended and then extracted with $10 \mathrm{ml}$ of $80 \%$ acetone and left for 15 minutes for thorough extraction. The liquid portion was decanted into another test-tube and centrifuged at 2,500rpm for 3 minutes. The supernatant was then collected and the absorbance taken at $645 \mathrm{~nm}$ and $663 \mathrm{~nm}$ using a spectrophotometer. Calculations were done using the formula below.

Chlorophyll a $=12-7 D X 643-2.69 D X 645$ X vmg $(\mathrm{mg} / \mathrm{g})$ $\div 1000$ w

Chlorophyll b = 22-9DX $645-24.68$ DX665 X vmg $(\mathrm{mg} / \mathrm{g}) \div$ $1000 \mathrm{w}$

$\mathrm{TCh}=$ Chlorophyll $\mathrm{a}+\mathrm{b}(\mathrm{mg} / \mathrm{g})$

$\mathrm{Dx}=$ Absorbance of the extract at the wavelength $(\mathrm{xnm})$

$\mathrm{V}=$ Total volume of the chlorophyll solution (ml)

$\mathrm{W}=$ Weight of the tissue extracted $(\mathrm{g})$.

Table 1: Plant Distribution in the Selected Areas

Location Coordinate Plants collected from
the location

\begin{tabular}{|c|c|c|}
\hline $\begin{array}{l}\text { LASUTH/ } \\
\text { Mobalaji }\end{array}$ & $\begin{array}{l}6^{0} 35^{\prime} 27.96^{\prime} \mathrm{N}, \\
3^{0} 20^{\prime} 25.43^{\prime} \mathrm{E}\end{array}$ & $\begin{array}{l}\text { Murraya panicullata, } \\
\text { Terminalia } \\
\text { Polyalthia longifolia, } \\
\text { Ficus }\end{array}$ \\
\hline Anthony & & Duranta repens \\
\hline $\begin{array}{l}\text { Government } \\
\text { Reservation } \\
\text { Area } \\
\text { (GRA) }\end{array}$ & $\begin{array}{l}6^{0} 33^{\prime} 59.46^{\prime} \mathrm{N}, \\
3^{0} 21^{\prime} 30.64^{\prime} \mathrm{E}\end{array}$ & $\begin{array}{l}\text { Murraya panicullata, } \\
\text { Terminalia catappa, } \\
\text { Polyalthia longifolia, } \\
\text { Ficus a benjamin, } \\
\text { Duranta repens }\end{array}$ \\
\hline State & $\begin{array}{l}6^{0} 35^{\prime} 32.16^{\prime} \mathrm{N}, \\
3^{0} 20^{\prime} 37.58^{\prime} \mathrm{E}\end{array}$ & $\begin{array}{l}\text { Murraya panicullata, } \\
\text { Terminalia catappa, } \\
\text { Polyalthia longifolia, } \\
\text { Ficus benjamin, } \\
\text { Duranta repens }\end{array}$ \\
\hline
\end{tabular}




\section{International Journal of Engineering Applied Sciences and Technology, 2019 Vol. 4, Issue 7, ISSN No. 2455-2143, Pages 217-221 \\ Published Online November 2019 in IJEAST (http://www.ijeast.com)}

\section{RESULTS}

The measured average height of Murraya panicullata, Terminalia catappa, Polyalthia longifolia, Ficus benjamin, Duranta repens are $16 \mathrm{~m}(52.5 \mathrm{ft}), 2.5 \mathrm{~m}(8.2 \mathrm{ft}), 34 \mathrm{~m}(111.5 \mathrm{ft})$, $30 \mathrm{~m}(98.4 \mathrm{ft})$ and $4 \mathrm{~m}(13.1 \mathrm{ft})$ respectively.

The total chlorophyll content of leaves of selected trees and shrubs as well as the carbon dioxide concentration in locations with and without trees or shrubs are presented in Table 2 and 3 . The data were expressed as means \pm standard error. Tables 2 shows that the highest sequestration takes place at LASUTH/Bank Anthony with a mean difference of 10.19 $\mathrm{mg} / \mathrm{ml}$. While secretariat with a mean difference of 5.83 $\mathrm{mg} / \mathrm{ml}$ shows the least level of sequestration. A closer look at Table 3 reveals that Almond (Terminalia catappa) has the highest mean chlorophyll content $(1.00 \mathrm{mg} / \mathrm{l})$ while Yellow bush (Duranta repens) has the lowest total chlorophyll content $(0.20 \mathrm{mg} / \mathrm{l})$. The difference proves that there was significant difference within the species.

Table 2: Comparison of mean carbon dioxide concentration in areas with and without trees and/or shrubs

\begin{tabular}{|c|c|c|c|}
\hline Location & $\begin{array}{l}\text { Mean }(\mathrm{mg} / \mathrm{ml}) \\
\text { Areas without } \\
\text { Trees/shrub }\end{array}$ & $\begin{array}{l}\text { Mean }(\mathrm{mg} / \mathrm{ml}) \\
\text { Areas with } \\
\text { Trees/shrub }\end{array}$ & $\begin{array}{l}\text { Percentage } \\
\text { different }(\%)\end{array}$ \\
\hline $\begin{array}{l}\text { LASUTH/Mobalaji } \\
\text { Anthony }\end{array}$ & $17.10 \pm 0.006^{\mathrm{a}}$ & $6.91 \pm 1.7$ & 10.19 \\
\hline Roundabout/Alausa & $15.16 \pm 0.06^{\mathrm{b}}$ & $18.18 \pm 1.36$ & 6.98 \\
\hline GRA & $14.60 \pm 0.06^{\mathrm{c}}$ & $8.49 \pm 2.26$ & 6.11 \\
\hline Secretariat & $11.10 \pm 0.06^{\mathrm{d}}$ & $5.27 \pm 0.9$ & 5.83 \\
\hline
\end{tabular}

Table 3: Mean total chlorophyll content of each species

\begin{tabular}{lllll}
\hline $\begin{array}{l}\text { Name of } \\
\text { Species }\end{array}$ & Common & Number & $\begin{array}{l}\text { Mean } \\
(\mathrm{mg} / \mathrm{g}) \\
\pm \mathrm{SE}\end{array}$ & $\begin{array}{l}\text { Standard } \\
\text { Deviation }\end{array}$ \\
& Name & of & & $(\mathrm{SD})$ \\
& & $\begin{array}{l}\text { Plant } \\
\text { sampled }\end{array}$ & \\
& & & \\
& &
\end{tabular}

\begin{tabular}{lllll}
\hline $\begin{array}{l}\text { Terminalia } \\
\text { catappa, }\end{array}$ & Almond & 12 & $1.00 \pm 0.02$ & 0.06 \\
$\begin{array}{l}\text { Polyalthia } \\
\text { longifolia, }\end{array}$ & Masqurade & 12 & $0.88 \pm 0.01$ & 0.13 \\
$\begin{array}{l}\text { Ficus } \\
\text { benjamin, }\end{array}$ & Ficus & 12 & $0.41 \pm 0.03$ & 0.10 \\
$\begin{array}{l}\text { Murraya } \\
\text { panicullata, }\end{array}$ & Murraya & 12 & $0.26 \pm 0.02$ & 0.06 \\
$\begin{array}{l}\text { Duranta } \\
\text { repens }\end{array}$ & $\begin{array}{l}\text { Yellow } \\
\text { bush }\end{array}$ & 12 & $0.20 \pm 0.03$ & 0.12 \\
\hline
\end{tabular}

\section{DiscUSSION}

An essential part of a process of carbon management is to calculate the carbon sequestered in trees (Xu and Mitchell, 2011). This study reveals the fact that in areas with trees and shrubs, the level of carbon dioxide is relatively low compared to areas without trees or shrubs. This fact is further proven by the difference in the means of the two areas compared. For instance, in LASUTH-Bank Anthony location, the mean carbon dioxide in areas without trees or shrub was $17.10 \pm 0.06$ $\mathrm{mg} / \mathrm{ml}$ while areas within the same location but with trees and shrubs have a carbon dioxide concentration of $6.91 \pm 1.73$ $\mathrm{mg} / \mathrm{ml}$. Even Secretariat which could be said to be the location with least sequestration potential (having a value of $11.10 \pm 0.06 \mathrm{mg} / \mathrm{ml}$ and $5.27 \pm 0.97 \mathrm{mg} / \mathrm{ml}$ for areas without and with trees and shrubs respectively) still has high carbon sequestration potential. The main factor that could be responsible for these great differences in sequestration function performed by the different plant species in these areas is their ability to act as $\mathrm{CO}_{2}$ sink; they do this by acting as sink for $\mathrm{CO}_{2}$, fixing carbon during photosynthesis and storing excess carbon as biomass. The finding here agrees with that of Lemon (1983) who worked on Bio façade and asserts that as Bio façade grows vertically up the side of the building, they provides more surface area to sink down the carbon dioxide level by photosynthesis.

Almond and masquerade with mean total chlorophyll content of $1.00 \pm 0.02 \mathrm{mg} / \mathrm{mI}$ and $0.88 \pm 0.01 \mathrm{mg} / \mathrm{ml} \mathrm{respectively} \mathrm{as}$ shown in Table 2 and 3 are the plants with the highest ability to sequester carbon dioxide. This observation among other factors could be due to morphological characters of the plants, such as girth of the tree or shrub, size, shape and orientation of the leaves as well as the lifespan of the plant. This finding is in consonance with the opinion of previous researchers since Almond and Masquerade trees are far larger in size than others which could at best be regarded as shrubs. For instance, Nowak (1994) asserts that large healthy trees greater than 77 $\mathrm{cm}$ in diameter sequester approximately 90 times more carbon 


\section{International Journal of Engineering Applied Sciences and Technology, 2019 \\ Vol. 4, Issue 7, ISSN No. 2455-2143, Pages 217-221 \\ Published Online November 2019 in IJEAST (http://www.ijeast.com)}

than small healthy trees less than $8 \mathrm{~cm}$ in diameter. Moreover, large trees with relatively long lifespan will generally have the greatest overall positive effect on carbon dioxide as fossil fuel carbon emission traps/sink resulting from tree planting and removal will happen more frequently. Trees store carbon in their leaves, branches, stems, bark and roots (Johnson and Coburn, 2010, p. 1). Carbon sequestration in trees can provide part of the answer to carbon offsetting, e.g. California State University offsets carbon emissions through quantifying carbon sequestration of its trees (Cox, 2012). This finding agrees with the work of Villiers et al. (2014) in which they calculated the carbon sequestered in trees on the main campus of KIWI University and estimated the annual expected sequestration over the next ten years.

\section{CONCLUSION}

The result of this research shows that sequestration of carbon dioxide in the metropolis is not negotiable. Urban trees and shrubs can play a significant role in helping to reduce atmospheric carbon dioxide levels. Carbon is absorbed and assimilated by tree foliage and is stored as carbon- rich organic compounds such as cellulose and hemicelluloses, lignin, starch, lipid and waxes mostly in secondary woody tissues in tree boles and in large roots, as well as in foliage, branches and fine roots. Our results and findings showed that these plant species absorb significant amount of carbon dioxide from the metropolis.

Furthermore, the study revealed that; of all the plant species used in the beautification and greening exercise in the study area, Almond and Masquerade have the highest capability to sequester carbon dioxide. The most important revelation from these is that trees in the study area have greater carbon dioxide sequestration potential than shrubs. Also there is need for more urban greening and beautification activity and as such the Local and State governments should continuously embark on trees and shrubs planting since it remains one of the cheapest, most effective means of sequestering excess $\mathrm{CO}_{2}$ from the atmosphere as well as in beautification of buildings and cities.

Despite the limited usefulness of carbon sequestration in trees, planting more trees trees like Almond and Masquerade trees form the basis for a formal and on-going carbon management programme, with the potential to do more. This research provides a useful foundation for future action on carbon sequestration in the state and country at large. It could form the basis to inform the on-going management of carbon sequestration, including the planning of new planting and decisions regarding the management of mature trees to improve the state's and country's environmental reputation.

\section{REFERENCES}

1. Solomon, S., Qin, D., Manning M., (2007). Climate Change 2007: The Physical Science Basis. New York: Cambridge University Press, (Pp.1-93).

2. IPCC, (2013). Climate Change 2013: The Physical Science Basis, available at: www.climatechange2013.org/images/uploads/WGI_AR5 _SPM_brochure.pdf

3. Speer, B.R. (1997). "Photosynthesis pigments". UCMP Glossary (online). University of California Museum of Paleontology. Available in March, 2007.

4. Sedjo, R.A. and Marland, G. (2003). "Inter-trading permanent emissions credits and rented temporary carbon emissions offsets: some issues and alternatives", Climate Policy, 3 (4), (pp. 435-444).

5. Fang, S., Gloor, M., Mahiman, J., Pacala, S., Sarmiento, J., Takahashi, T. and Tans, P. (2007). A large terrestrial carbon sinks in North America implied by atmospheric and oceanic carbon dioxide data and models. Science, 282: (pp. 442-446).

6. Andrasko, K. (1990). Climate Change and Global Forests: An overview of current knowledge of Potential Effects, Adaption and Mitigation Options. Unasylva, 41: (pp. 3-11).

7. Brown, S., Hall, C.A.S., Knabe, W., Raich, J., Trexler, M.C. and Woomer, P. (1993). Tropical forests: their past, present, and potential role in the terrestrial Carbon budget. Water, Air and Soil Pollution, 70: (pp. 71-94).

8. Cannell, M.G.R., Mime, R., Haigreaves, K.J., Brown, T.A.W., Cruickshank, M.M., Bradley, R.I., Spencer, T., Hope, D., Billet, M.F., Adger, W.N., and Subak, S. (1999). National inventories of terrestrial carbon sources and sinks: the UK experience. Climate Change, 42 (3): (pp. 505-530).

9. Dai, M.H., Zhai, W.D., and Lu, Z.M. (2004). Regional studies of carbon cycles in China: progress and perspectives. Advance in Earth Research, 2(19): (pp. 120-130).

10. Tiwari, A.K and Singh, J.S. (1987). Analysis of Forest Land use and Vegetation in a part of Cifitl Himalaya, Using Aerial photographs, Environmental Conserve, 14: (pp. 233-244).

11. Brown, S. and Gaston, G. (1995). Use of forest inventories and geographic information systems to estimate biomass density of tropical forests: Application to tropical Africa. Environmental Monitoring and Assessment, 38: (pp. 157-168).

12. Oyedepo, S.A. (2012). On Energy for Sustainable Development in Nigeria. Renewable and Sustainable Energy Reviews 16: (pp. 2583-2598). http://www.energsustainsoc.com/content/2/1/15 
13. Nodza, I.G., Onuminya, T.O. and Ogundipe, O.T. (2014). A checklist of tree species growing on akoka campus of University of Lagos, Nigeria. International Journal of Science, Environment and Technology, 3 (3): (pp. 1021 - 1034).

14. Akanni. C.O. (1992). Climate in Ogun State of Nigeria in maps (eds). 3. Rex Charles Publication, Ibadan. (Pp.21 23).

15. Larson, R.E., Hostetler, R.P. and Edwards, B.H. (1993). Precalculus: A Graphing Approach. D. C. Heath and Company, Lexington, MA. (Pp. 654).

16. Waring, R.H. and Schlesinger, W.H. (1985). Forest Ecosystems: Concepts and Management. Academic Press, Inc. San Diego, CA. (Pp. 340).

17. Arnon, D. I. (1949); Copper Enxymes in Isolated Chloroplasts Polyphenol Oxidase in Beta Vulgaris. Plant Physiol. 24(1): (1-15).

18. Lemon, E.R. (1983). $\mathrm{CO}_{2}$ and Plants. The response of plants to rising levels of atmospheric carbon dioxide. In: Lemon, E.R (eds). AAAS Selected Symposium, 84. Westview Press, Boulder, CO.

19. Xu, B. and Mitchell, N. (2011), "Carbon sequestration by trees on the city campus", unpublished working paper, The University of Auckland, Auckland.

20. Nowak, D.J. (1994). Atmospheric carbon dioxide reduction by Chicago's urban forest. In: McPherson, E.G., Nowak, D.J., Rowntree, R.A. (Eds.), Chicago's Urban Forest Ecosystem: Results of the Chicago Urban Forest Climate Project. USDA Forest Service General Technical Report NE-186, Radnor, PA, (pp. 83-94).

21. Villiers, C.D., Chen, S., Chenxing, J. and Yiner, Z. (2014). Carbon sequestered in the trees on a university campus: a case study. Sustainability Accounting, Management and Policy Journal, 5(2): (pp. 149-171). DOI 10.1108/SAMPJ-11-2013-0048.

22. Cox, H.M. (2012). "A sustainability initiative to quantify carbon sequestration by campus trees", Journal of Geography, 111(5): (pp. 173-183).

23. Johnson, I. and Coburn, R. (2010). Trees for Carbon Sequestration, Vol. 19, available at: www.dpi.nsw.gov.au/data/assets/pdf_file/0003/317559/T rees-for-carbon-sequestration.pdf (accessed 19 August 2012). 